\title{
PENGARUH VOLUME OFFER SAHAM TERHADAP HARGA SAHAM \\ (STUDI EMPIRIS PADA SAHAM-SAHAM JAKARTA ISLAMIC INDEX DI BURSA EFEK INDONESIA \\ PERIODE JANUARI - APRIL 2020) \\ KAJIAN PENELITIAN PADA KONDISI PANDEMI VIRUS COVID-19
}

\author{
Sunaryo \\ Program Studi Magister Manajemen, Fakultas Ekonomi dan Bisnis \\ Universitas Islam As-Syafi'iyah \\ sunaryo56@gmail.com
}

\begin{abstract}
The purpose of this research was to determine the influence of offering volume stock on the stock price. This research sample is shared in the sharia category in the JII group (Jakarta Islamic Index) listed on the Indonesia Stock Exchange (IDX) period January-April 2020 by using a saturated sampling method. There were 20 stocks selected as samples. The research method used in this research is panel data regression. The results of the study showed that the offer volume stock has a significant and negative influence on the stock price.
\end{abstract}

Keywords : Offering Volume Stock and Stock Price

\begin{abstract}
Abstrak. Tujuan penelitian ini untuk mengetahui pengaruh volume offer saham terhadap harga saham. Sampel penelitian ini adalah saham-saham dalam kategori syariah dalam kelompok JII (Jakarta Islamic Index) yang terdaftar di Bursa Efek Indonesia (BEI) periode Januari-April 2020 dengan menggunakan metode sampel jenuh. Ada 20 saham yang dipilih sebagai sampel. Metode penelitian yang digunakan dalam penelitian ini adalah regresi data panel. Hasil penelitian menemukan volume offer saham memengaruhi harga saham secara negatif dan signifikan.
\end{abstract}

Kata kunci: Volume Offer Saham dan Harga Saham 


\section{PENDAHULUAN}

\subsection{Latar Belakang Penelitian}

Memasuki tahun 2020 dunia dikejutkan munculnya virus corona. Rizal (KOMPAS.com) mengemukakan, sebagian besar orang meyakini bahwa kisah awal penyebaran virus corona Covid-19 bermula pada akhir 2019 ketika seseorang terjangkit virus corona dari hewan yang diperdagangkan di pasar seafood Huanan, kota Wuhan, provinsi Hubei, China.

Berdasarkan sumber dari CNBC Indonesia, yang mengutip dari situs WHO, virus corona adalah keluarga besar virus yang dapat menyebabkan penyakit pada hewan atau manusia. Dampak corona pada manusia diketahui melalui gejala infeksi pernafasan dimulai flu biasa hingga penyakit yang lebih kronis seperti Middle East Respiratory Syndrome (MERS), dan Severe Acute Respiratory Syndrme (SARS). Akibat penyebaran virus corona, Worldometers mencatat pada Jumat (3/4/2020), pukul 19.15 ada 1.033.210 kasus dengan 54.442 kematian. Worldometers juga mencatat peta penyebaran virus corona John Hopkins ada 1.030.628 kasus dengan 54.137 kematian. Amerika Serikat saat ini adalah yang memiliki kasus terbanyak, yakni 245.573 kasus. Sementara itu New York mencatat kematian terbanyak dengan 1.562 orang (Worldometers).

Merebaknya virus corona di Indonesia pada awal bulan Maret 2020, dan memulai dilakukannya perperangan untuk menghadapi pandemi Virus Corona (Virus Covid 19). Masuknya pertama kali Virus Covid 19 di Indonesia tidak hanya berdampak terhadap kesehatan tetapi juga berdampak secara tidak langsung terhadap perekonomian. Dikutip dari CNN Indonesia, dampak dari virus corona Menteri Keuangan Republik Indonesia Sri Mulyani mengatakan bahwa pertumbuhan ekonomi Indonesia diproyeksi dapat dicapai 2,3\%. Bahkan, dalam kondisi yang paling buruk, ekonomi bisa dicapai minus hingga $0,4 \%$. Penyebab dari hal ini antara lain adalah menurunnya konsumsi dan investasi, baik dalam lingkup rumah tangga maupun lingkup pemerintah.

Dampak dari Virus Corona (Virus Covid 19) di sektor pasar keuangan dan pasar modal adalah menyebabkan kurs dollar terhadap rupiah meninggi hingga mencapat Rp 16.000/\$US, Indeks Harga Saham Gabungan (IHSG) di Bursa Efek Indonesia (BEI) menunjukkan terjadi penurunan dalam beberapa minggu terakhir bulan Maret 2020. Bagaimana perkembangan Kurs dan IHSG selama pandemi virus corona berikut ini disajikan tabelnya.

Tabel 1. Perkembangan Kurs Tengah BI Rp/USD Januari - April 2020

\begin{tabular}{ccccc}
\hline & \multicolumn{4}{c}{ Akhir bulan tahun 2020 } \\
\cline { 2 - 5 } & Januari & Februari & Maret & April \\
\hline Kurs (Rp) & 13.655 & 14.234 & 16.367 & 15.157 \\
\hline Sumber : Bank Indonesia & & &
\end{tabular}

Dari tabel 1 di atas tergambar kurs rupiah terhadap US dolar dari bulan Januari sampai dengan bulan Maret 2020 meningkat cukup signifikan, dan bulan April 2020 menurun dibandingkan Maret 2020, namun masih dikategorikan pada posisi yang cukup tinggi. Peningkatan kurs pada bulan-bulan tersebut sejalan dengan merebaknya selama pandemi virus corona di Indonesia. Selanjutnya bagaimana kondisi perkembangan IHSG berikut ini disajikan tabel 2. 
Tabel 2. Perkembangan IHSG Januari - April 2020

\begin{tabular}{lcccc}
\hline & \multicolumn{4}{c}{ Akhir bulan tahun 2020 } \\
\cline { 2 - 5 } & Januari & Februari & Maret & April \\
\hline IHSG & $6.057,59$ & $5.452,70$ & $4.538,93$ & $4.642,47$ \\
\hline Sumber : BEI & & & &
\end{tabular}

Dari tabel 2 di atas tergambar Indeks Harga Saham Gabungan (IHSG) dari bulan Januari sampai dengan bulan Maret 2020 menurun cukup signifikan, dan bulan April 2020 meningkat tidak begitu signifikan dibandingkan Maret 2020. Penurunan IHSG pada bulan-bulan tersebut sejalan dengan merebaknya selama pandemi virus corona di Indonesia.

Merebaknya virus corona tanpa terkecuali berdampak juga terhadap saham-saham yang berbasis syariah, hal ini tergambar dari Jakarta Islamic Index (JII) di Bursa Efek Indonesia (BEI). Bagaimana kondisi perkembangan JII berikut ini disajikan tabel 3.

Tabel 3. Perkembangan JII Januari - April 2020

\begin{tabular}{lcccc}
\hline & \multicolumn{4}{c}{ Akhir bulan tahun 2020 } \\
\cline { 2 - 5 } & Januari & Februari & Maret & April \\
\hline JII & 642.804 & 565.007 & 476.388 & 542.496 \\
\hline Sumber : BEI & & & &
\end{tabular}

Dari tabel 3 di atas tergambar JII yang mencerminkan harga saham syariah dari bulan Januari sampai dengan bulan Maret 2020 menurun cukup signifikan, dan bulan April 2020 meningkat tidak begitu signifikan dibandingkan Maret. Penurunan JII pada bulan-bulan tersebut sejalan dengan merebaknya selama pandemi virus corona di Indonesia.

Berdasarkan sumber CNN Indonesia (07/04/2020), Otoritas Jasa Keuangan (OJK) mengungkapkan bahwa Indeks Harga Saham Gabungan (IHSG) merosot tajam hingga menyentuh level terendah dalam sejarah akibat penyebaran virus corona.

Wimboh (Ketua Dewan Komisioner OJK) lebih lanjut mengungkapkan, sejak awal tahun investor non residen alias investor asing melarikan modal mereka dari pasar saham sebesar Rp11,3 triliun. Sedangkan dana asing yang keluar berasal dari pasar Surat Berharga Negara (SBN) lebih besar yakni Rp129,2 triliun.

Menurut OJK (12/03/2020) yang dikutip Rully R. Ramli (Kompas.com), "Virus corona sebagai salah satu sentimen negatif yang terus menekan kinerja ekonomi global sejak awal tahun ini”. Sentimen negatif ini menyebabkan investor asing melarikan modal mereka dari pasar saham Indonesia, pada kondisi seperti ini menyebabkan terjadi penawaran saham yang berlebihan. Sebagaimana diungkap Umam dan Sutanto (2017), jika terjadi kelebihan penawaran saham dibandingkan permintaan saham, maka harga saham cenderung turun.

Secara teoritis banyak faktor yang memengaruhi pergerakan harga saham, seperti Tandelilin (2010) mengemukakan harga saham sangat tergantung dari prospek keuntungan yang dimiliki perusahaan, dan keuntungan tersebut tergantung kondisi makro ekonomi seperti produk domestik bruto, tingkat pengangguran, inflasi, tingkat bunga, kurs Rupiah terhadap US dolar. Menurut Alwi (2008) faktor-faktor yang mempengaruhi pergerakan harga saham yaitu diantaranya, Earning Per Share (EPS), Dividen Per Share (DPS), Price Earning Ratio, Net Profit Margin, Return on Assets 
(ROA), dan lain-lain. Menurut Fahmi (2014), faktor yang memengaruhi harga pasar salah satunya yaitu efek psikologi pasar yang ternyata mampu menekan kondisi teknikal jual beli saham. Efek psikologi pasar ini yang menimbulkan sentimen negatif.

Faktor permintaan dan penawaran saham yang memengaruhi harga saham pada dasarnya merupakan faktor yang berpengaruh langsung. Sedangkan faktor tidak langsungnya adalah faktor seperti yang telah diuraikan oleh Tandelilin, Alwi dan Fahmi.

Secara empiris terdapat peneliti yang telah melakukan penelitian yang berhubungan dengan volume offer saham terhadap harga saham seperti Tenriola \& Akramunnas (2017) dan Tri Nendhenk \& Masdar (2019) menemukan volume perdagangan saham berpengaruh positif dan signifikan terhadap harga saham. Widayanti \& Mulyo (2013) menemukan volume perdagangan saham berpengaruh positif dan signifikan terhadap return saham. Bram dan Setiawan (2007) menemukan hasil bahwa volume perdagangan saham berpengaruh positif dan signifikan terhadap return saham. Namun Sugeng \& Raden Rustam (2016) menemukan volume bid secara parsial tidak berpengaruh terhadap harga saham. Ariyani \& Zumrotun (2017) menemukan volume perdagangan saham menunjukkan hasil positif namun tidak signifikan terhadap return saham. Muhammad (2019) menemukan trading volume berpengaruh tidak signifikan terhadap return saham.

Dari uraian tersebut di atas tergambar data-data fenomena dilapangan menunjukkan bahwa harga saham syariah yang tercermin dalam JII menunjukkan penurunan pada kondisi merebaknya covid 19, disamping itu penelitian terdahulu yang tidak konsisten temuannya. Oleh karena itu penelitian ini mencari faktor penyebab yang signifikan memengaruhi harga saham dalam JII.

\subsection{Perumusan Masalah}

Dari uraian latar belakang penelitian di atas, dapat diidentifikasikan masalah penelitian yaitu bahwa disinyalir banyak faktor yang memengaruhi harga saham. Dalam penelitian ini hanya difokuskan pada faktor penawaran volume saham atau volume offer saham. Pemilihan faktor tersebut didasarkan pertimbangan bahwa penyebaran Covid-19 terjadi antar hari yang dirasakan sangat signifikan mulai bulan Februari 2020, oleh karena itu faktor (variabel independen) yang digunakan dalam kajian penelitian ini juga harus faktor yang dapat berfluktuasi secara harian. Faktor yang relevan yaitu penawaran volume saham, disamping itu juga terdapat sumber yaitu Wimboh (Ketua Dewan Komisioner OJK) yang mengatakan bahwa virus corona sebagai salah satu sentimen negatif yang terus menekan kinerja ekonomi global sejak awal tahun ini, sehingga berdampak investor saham yang melepas sahamnya.

Berdasarkan pembatasan masalah dan atas dasar fenomena gap serta research gap, maka perlu dilakukan penelitian lanjutan dengan mengajukan pertanyaan penelitian : Apakah volume offer saham berpengaruh terhadap harga saham dalam kelompok JII pada kondisi pandemi virus Covid-19?

\subsection{Tujuan Penelitian}

Tujuan penelitian ini untuk mengetahui, menganalisis dan memperoleh bukti empiris mengenai pengaruh volume offer saham terhadap harga saham dalam kelompok JII pada kondisi pandemi virus Covid-19. 


\subsection{Manfaat Penelitian}

Hasil penelitian ini diharapkan dapat bermanfaat bagi :

(1) Investor

Secara praktis, hasil penelitian ini diharapkan dapat bermanfaat bagi investor di Pasar Modal sebagai informasi dalam mempertimbangkan keputusannya untuk investasi saham yang berbasis syariah pada kondisi yang tidak normal.

(2) Akademik

Secara teoritis, hasil penelitian ini diharapkan dapat menjadi tambahan pengetahuan dan referensi bagi peneliti selanjutnya.

\section{TINJAUAN PUSTAKA DAN HIPOTESIS}

\subsection{Landasan Teori}

\subsubsection{Jakarta Islamic Index}

Di BEI terdapat saham syariah yang dapat menjadi pilihan bagi investor yang memperhatikan penerapan syariat agama Islam atau saham yang berbasis syariah dalam kegiatan berinvestasi. Pengertian saham yang berbasis saham syariah berdasarkan undang-undang maupun peraturan OJK lainnya, yaitu ada dua jenis saham syariah yang diakui di pasar modal Indonesia. Syarat pertama, saham yang dapat memenuhi kriteria seleksi saham syariah berdasarkan adalah peraturan OJK Nomor 35/POJK.04/2017 tentang Kriteria dan Penerbitan Daftar Efek Syariah, yang kedua adalah kategori sebagai saham yang dicatat saham syariah oleh emiten atau perusahan publik syariah atas dasar peraturan OJK no. 17/POJK.04/2015. Indeks saham syariah yang digunakan sebagai indikator untuk mengamati pergerakan harga sahamnya adalah Jakarta Islamic Index (JII). JII sebagai indeks saham syariah diluncurkan pertama kali di pasar modal Indonesia pada tanggal 3 Juli 2000. Saham dalam kelompok JII terdiri dari 30 saham syariah paling likuid yang tercatat di BEI. BEI menentukan dan melakukan seleksi saham syariah yang menjadi syarat JII sebagai berikut (sumber Fahmi, 2014:311) :

- Saham dipilih harus sudah tercatat paling tidak 3 bulan terakhir, kecuali saham yang termasuk 10 kapitalisasi besar.

- Mempunyai Rasio hutang terhadap Aktiva tidak lebih besar dari 90\% dilaporan keuangan tahunan atau tengah tahun.

- Dari yang masuk kriteria 1 dan 2, dipilih 60 saham dengan urutan rata-rata kapitalisasi pasar terbesar selama satu tahun terakhir.

- Kemudian dipilih 30 saham dengan urutan tingkat likuiditas rata-rata nilai perdagangan regular selama tahun terakhir.

Pergerakan JII dapat digunakan sebagai acuan bagi investor maupun calon investor dalam berinvestasi di BEI dalam rangka untuk mendapatkan imbal hasil. Kebanyakan investor yang melakukan investasi saham di pasar modal mengharapkan untuk memperoleh return yang utama dalam bentuk capital gain. 


\subsubsection{Volume Offer Saham}

Dikutip dari IndoPremier (www.indopremier.com), Bid merupakan urutan berbagai macam harga dimana pembeli bersedia membeli sebuah saham, sedangkan Offer merupakan urutan berbagai macam harga dimana penjual bersedia menjual sahamnya. Semakin meningkatnya permintaan saham dengan terus melakukan pembelian saham karena baiknya kualitas perusahaan dan mempunyai potensi untuk terus berkembang ke depannya, maka harga saham akan cenderung naik. Sebaliknya, jika kualitas perusahaan tersebut tidak sehat dan mempunyai bisnis denga risiko yang besar, maka harga sahamnya akan menurun dikarenakan sedikitnya investor berminat membeli saham tersebut.

Bid dan offer di bursa tercermin dari volume perdagangan saham. Volume perdagangan saham mencerminkan kekuatan antara supply dan demand yang merupakan perwujudan dari tingkah laku investor. Dengan naiknya volume perdagangan maka keadaan pasar dapat dikatakan menguat, demikian pula sebaliknya (Ang, 1997). Menguat atau istilah populernya Bullish, dan melemah istilah populernya Bearish.

Pendekatan untuk menganalisis permintaan dan penawaran saham menggunakan analisis teknikal. Menurut Meyer (1989) yang dikutip oleh Tandelilin (2010), analisis teknikal adalah studi terhadap suatu sekuritas atau pasar secara keseluruhan berdasarkan permintaan dan penawaran. Data historis harga dan aktivitas volume transaksi diolah terutama dalam bentuk chart untuk meramalkan trend harga masa depan (Tandelilin: 2010). Salah satu asumsi yang digunakan dalam analisis teknikal menurut Levy (1966) yang dikutip oleh Tandelilin (2010) adalah trend perubahan dan nilai pasar dapat berubah karena hubungan permintaan dan penawaran.

Menurut Levy (1966) yang dikutip oleh Tandelilin (2010), permintaan dan penawaran saham ditentukan oleh faktor ekonomi dan variabel fundamental serta faktor-faktor opini yang beredar, mood investor, dan ramalan-ramalan investor.

\subsubsection{Harga Saham}

Nilai pasar (market value) merupakan nilai saham di pasar saham Jogiyanto (2017:199). Lebih lanjut Jogiyanto (2017:2008) mengemukakan: "nilai pasar (market value) berbeda dengan nilai buku, jika nilai buku merupakan nilai yang tercatat pada saat saham dijual oleh perusahaan, maka nilai pasar adalah harga saham yang terjadi di pasar bursa pada saat tertentu yang ditentukan oleh pelaku pasar dan nilai pasar ini ditentukan oleh permintaan dan penawaran saham bersangkutan di pasar bursa".

Menurut Fahmi (2014:329) terdapat beberapa faktor yang mempengaruhi naik turunnya harga saham yaitu :

(1) Kondisi mikro dan makro ekonomi.

(2) Keputusan perusahaan dalam memutuskan untuk ekspansi (perluasan usaha), seperti membuka kantor cabang (brand office), kantor cabang pembantu (sub brand office) baik yang dibuka di domestik maupun luar negeri.

(3) Pergantian direksi secara tiba-tiba.

(4) Adanya direksi atau komisaris perusahaan yang terlibat dalam tindak pidana dan kasusnya sudah masuk ke pengadilan.

(5) Kinerja perusahaan yang terus mengalami penurunan dalam setiap waktunya. 
(6) Risiko sistematis, yaitu risiko yang terjadi secara menyeluruh dan telah ikut menyebabkan perusahaan ikut terlibat.

(7) Efek psikologi pasar yang ternyata mampu menekan kondisi teknikal jual beli saham.

\subsection{Kerangka Pemikiran Teoritis dan Perumusan Hipotesis}

Pengaruh Volume Offer Saham terhadap Harga Saham. Hukum permintaan dan penawaran sangat berpengaruh terhadap harga suatu saham. Seperti yang dikemukan oleh Umam dan Sutanto (2017:176-177), harga saham cenderung naik apabila suatu saham mengalami kelebihan permintaan diatas penawaran dan cenderung turun jika terjadi kelebihan penawaran. Terkait dengan permintaan dan penawaran saham, Syamsir (2006:5) mengemukakan : "asumsi dasar dalam analisis teknikal adalah bahwa harga sangat ditentukan oleh keseimbangan antara supply dan demand, jika terjadi ekses supply (kelebihan supply atas demand), maka harga akan jatuh dan demikian sebaliknya."

Kelebihan penawaran saham ini mencerminkan banyaknya investor di bursa yang melepas atau menjual sahamnya seperti yang tercermin dalam kondisi merebaknya Covid-19. Menurut OJK (12/03/2020) seperti yang dikutip Rully R. Ramli (Kompas.com), "Virus corona sebagai salah satu sentimen negatif yang terus menekan kinerja ekonomi global sejak awal tahun ini". Sentimen negatif ini menyebabkan investor asing melarikan modal mereka dari pasar saham, pada kondisi seperti ini menyebabkan terjadi penawaran saham yang berlebihan. Penelitian terdahulu Tenriola \& Akramunnas (2017) dan Tri Nendhenk \& Masdar (2019) menemukan volume perdagangan saham berpengaruh positif dan signifikan terhadap harga saham. Widayanti \& Mulyo (2013) menemukan volume perdagangan saham berpengaruh positif dan signifikan terhadap return saham. Bram dan Setiawan (2007) menemukan hasil bahwa volume perdagangan saham berpengaruh positif dan signifikan terhadap return saham.

Hasil penelitian terdahulu tersebut menemukan bahwa volume perdagangan berpengaruh positif terhadap harga, sesuai kajian teori bahwa pengaruh positif berarti pada posisi permintaan lebih besar dari penawaran saham, dan jika permintaan lebih kecil dari penawaran saham sesuai kajian berarti berpengaruh negatif terhadap harga saham.

Atas dasar teori dan hasil penelitian terdahulu tersebut, maka hipotesis dalam penelitian ini sebagai berikut:

H: Volume Offer Saham berpengaruh negatif terhadap harga saham. 


\section{KERANGKA PEMIKIRAN TEORITIS}

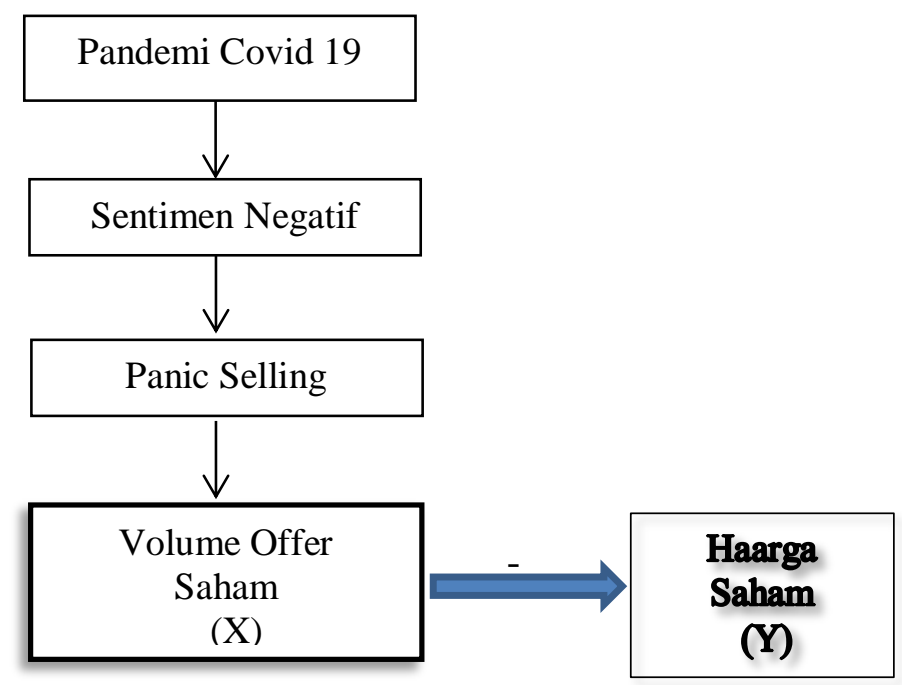

Gambar Kerangka Pemikiran Teoritis

\section{METODE PENELITIAN}

Populasi penelitian ini adalah saham-saham dalam kategori syariah dalam kelompok JII (Jakarta Islamic Index) untuk Periode: Desember 2019 - Mei 2020 yang terdaftar berdasarkan lampiran pengumuman BEI No Peng-00555/BEI.POP/11-2019. Sampel yang digunakan adalah sampel jenuh (populasi), berikut daftar saham yang masuk ke dalam indeks JII yang disajikan pada tabel 4.

\section{Tabel 4. Daftar Saham Terpilih Sebagai Sampel}

\begin{tabular}{|c|c|l|l|}
\hline No & Kode Saham & \multicolumn{1}{|c|}{ Name } & \multicolumn{1}{|c|}{ Sektor } \\
\hline 1 & ADRO & Adaro Energy Tbk. & Mining \\
2 & AKRA & AKR Corporindo Tbk. & Trade, Service \& Investment \\
3 & ANTM & Aneka Tambang (Persero) Tbk. & Mining \\
4 & ASII & Astra International Tbk. & Misc Industry \\
5 & BRPT & Barito Pacific Tbk. & Chemical Industry \\
6 & BSDE & Bumi Serpong Damai Tbk. & Property \& Construction \\
7 & BTPS & Bank Tabungan Pensiunan National Syariah Tbk & Finance \\
8 & CPIN & Charoen Pokphand Indonesia Tbk. & Chemical Industry \\
9 & CTRA & Ciputra Development Tbk. & Property \& Construction \\
10 & ERAA & Erajaya Swasembada Tbk. & Trade, Service \& Investment \\
11 & EXCL & XL Axiata Tbk. & Infrastructure \& Transportation \\
12 & ICBP & Indofood CBP Sukses Makmur Tbk. & Consumer Goods \\
13 & INCO & Vale Indonesia Tbk. & Mining \\
14 & INDF & Indofood Sukses Makmur Tbk. & Consumer Goods \\
15 & INTP & Indocement Tunggal Prakarsa Tbk. & Chemical Industry \\
16 & ITMG & Indo Tambangraya Megah Tbk. & Mining \\
17 & JPFA & JAPFA Comfeed Indonesia Tbk. & Chemical Industry \\
18 & JSMR & Jasa Marga (Persero) Tbk. & Infrastructure \& Transportation \\
& & &
\end{tabular}


Jenis data yang digunakan dalam penelitian ini adalah data sekunder yang berupa data harian harga saham dan volume penawaran saham mulai 2 Januari 2020 hingga 30 April 2020.

Sumber data diperoleh dari PT Bursa Efek Indonesia untuk data penawaran saham dan Investing.com untuk harga saham.

Tabel 5. Definisi Operasional Variabel

\begin{tabular}{|c|c|c|c|}
\hline Variabel & Konsep & Operasional Variabel & Skala \\
\hline $\begin{array}{l}\text { Volume } \\
\text { Saham }\end{array}$ & $\begin{array}{l}\text { Volume Offer Saham adalah } \\
\text { penawaran jual, minat jual } \\
\text { atau antri jual }\end{array}$ & $\begin{array}{l}\text { Volume Offer adalah jumlah } \\
\text { lot penawaran saham } \\
\text { Volume Offer Saham =Ln } \\
\text { (jumlah lot penawaran saham) }\end{array}$ & Rasio \\
\hline Harga Saham & $\begin{array}{l}\text { Nilai pasar (market value) } \\
\text { merupakan nilai saham di } \\
\text { pasar saham Bursa Efek } \\
\text { Indonesia }\end{array}$ & $\begin{array}{l}\text { Harga saham penutupan per } \\
\text { hari dari } 2 \text { Januari hingga } 30 \\
\text { April } 2020 \\
\text { Harga Saham =Ln (Rp Harga } \\
\text { saham) }\end{array}$ & Rasio \\
\hline
\end{tabular}

Metode analisis yang digunakan adalah model regresi data panel dengan formula berikut:

$$
\begin{aligned}
& \text { Metode Common Effect : } Y_{i t}=\beta_{0}+\beta X_{i t}+\varepsilon_{i t} \\
& \text { Metode Fixed Effect }: Y_{i t}=\beta_{0 i}+\beta X_{i t}+\varepsilon_{i t} \\
& \text { Metode Random Effect }: Y_{i t}=\beta_{0 i}+\beta X_{i t}+\varepsilon_{i t}
\end{aligned}
$$

Keterangan:

$\beta_{0}=$ Konstanta Metode Common Effect

$\beta_{0 \mathrm{i}}=$ Konstanta Metode Fixed Effect

$\mathrm{Y}=$ Harga Saham; $\mathrm{X}=$ Volume Offer Saham

$\mathrm{i}=$ saham-saham, $\mathrm{t}=$ waktu, $\varepsilon=$ Error/variabel gangguan

$\beta_{0}$ adalah intersep dengan asumsi tidak ada perbedaan antar individu/unit $\beta_{0 \mathrm{i}}$ adalah intersep dengan asumsi ada perbedaan antar individu/unit 


\section{HASIL PENELITIAN DAN PEMBAHASAN}

\section{Hasil Penelitian}

\section{Analisis Regresi Data Panel}

\subsection{Uji Fixed Effect (Uji Chow)}

\section{Tabel 6. Output Uji Chow}

Redundant Fixed Effects Tests

Pool: POOL01

Test cross-section fixed effects

\begin{tabular}{lrrr}
\hline \hline Effects Test & Statistic & d.f. & Prob. \\
\hline \hline Cross-section F & 913.762483 & $(19,1652)$ & 0.0000 \\
Cross-section Chi-square & 4087.409865 & 19 & 0.0000 \\
\hline
\end{tabular}

Sumber : Output Pengolahan Eviews9

Dari Tabel 6 diatas, menunjukkan probability (p-value) cross section F sebesar $0.000<0,05$ dengan taraf signifikansi sebesar $5 \%$, maka dapat diputuskan bahwa Ho ditolak atau dapat dikatakan bahwa model yang yang lebih baik adalah Fixed Effect daripada Common Effect. Setelah Uji Chow selesai dilaksanakan, maka dilanjutkan dengan Uji Hausman.

\subsection{Uji Fixed Effect atau Random Effect (Uji Hausman)}

\section{Tabel 7. Output Uji Hausman}

Correlated Random Effects - Hausman Test

Pool: POOL01

Test cross-section random effects

\begin{tabular}{lrrr}
\hline \hline Test Summary & $\begin{array}{c}\text { Chi-Sq. } \\
\text { Statistic }\end{array}$ & Chi-Sq. d.f. & Prob. \\
\hline \hline Cross-section random & 44.589189 & 1 & 0.0000 \\
\hline \hline
\end{tabular}

Sumber : Output Pengolahan Eviews9

Hasil Uji Hausman pada Tabel 7 diatas, menunjukkan p-value cross-section random sebesar $0.000<0.050$ dengan taraf signifikansi sebesar 5\%, maka dapat diambil kesimpulan bahwa model regresi data panel yang digunakan adalah Model Fixed Effect dimana lebih baik daripada Model Random.

\section{Pengujian Hipotesis dengan Regresi Data Panel Fixed Effect}

\section{Tabel 8. Output Regresi Data Panel Model Fixed Effect}

Dependent Variable: PRICE?

Method: Pooled EGLS (Cross-section weights)

Sample: 184

Included observations: 84

Cross-sections included: 20

Total pool (unbalanced) observations: 1673

Linear estimation after one-step weighting matrix 
KINERJA Jurnal Ekonomi dan Bisnis Vol. 2 No. 2 - Juni 2020

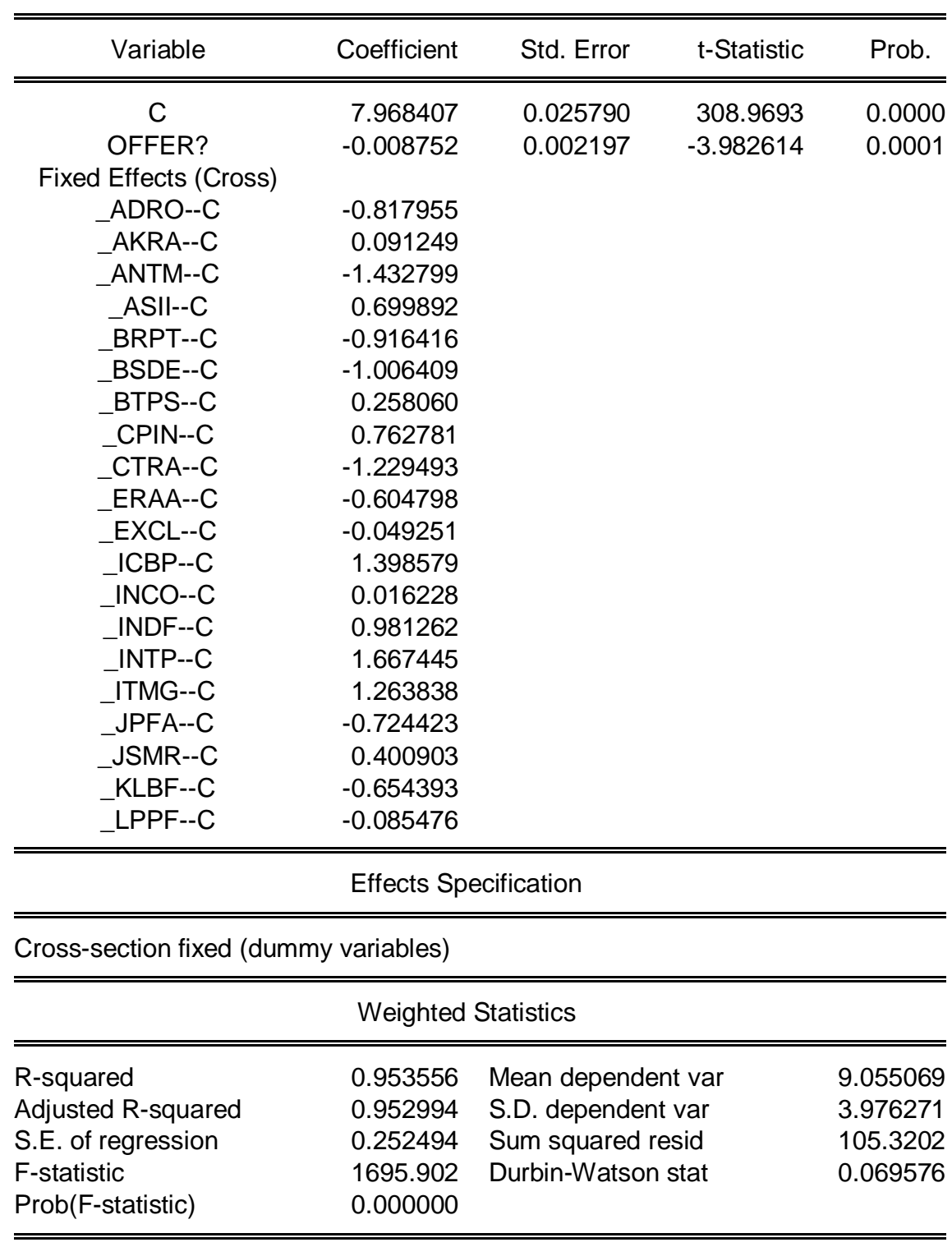

Sumber : Output Pengolahan Eviews9

Berdasarkan Tabel 8 dirumuskan persamaan model regresi data panel model Fixed Effect sebagai berikut:

$\mathrm{Y}=7.9684-0.00875 \mathrm{X}$

Koefisien sebesar -0.00875 , memberikan makna Y (harga saham) akan turun sebesar 0.00875 jika $X$ (volume offer saham) naik sebesar 1 dengan asumsi faktor diluar $\mathrm{X}$ dianggap konstan.

Model Fixed Effect merupakan metode regresi data panel yang mengasumsikan terdapat perbedaan antar unit (perusahaan) atau intersep bervariasi antar unit. Dari tabel 8 di atas terlihat dari 20 perusahaan yang masuk dalam JII, INTP (Indocement Tunggal Prakarsa Tbk.) intersep yang tertinggi yaitu sebesar 1.6674, diikuti ANTM (Aneka Tambang Tbk.) sebesar 1.4327, ICBP (Indofood CBP Sukses Makmur Tbk) sebesar 1.3985, dan ITMG (Indo Tambangraya Megah Tbk.) sebesar 1.2638 CTRA (Ciputra Development Tbk.) sebesar 1.2294. 
Intersep yang tinggi memberikan makna bahwa jika diasumsikan variabel bebas penelitian yaitu volume offer saham tidak berpengaruh, maka kelima perusahaan tersebut memiliki rata-rata perubahan harga saham yang tinggi dibandingkan perusahaan lainnya. Rata-rata perubahan harga saham yang tinggi mencerminkan tingkat volatilitas tinggi dan menggambarkan risiko yang tinggi.

Intersep yang paling rendah adalah perusahaan INCO (Vale Indonesia Tbk) sebesar 0.016228, hal ini memberikan makna bahwa jika diasumsikan variabel bebas penelitian yaitu volume offer tidak berpengaruh, maka perusahaan tersebut memiliki rata-rata perubahan harga saham yang rendah dibandingkan perusahaan lainnya. Ratarata perubahan harga saham yang rendah mencerminkan tingkat volatilitas rendah dan menggambarkan risiko yang rendah.

\section{Koefisien Determinasi $\left(\mathbf{R}^{2}\right)$}

Dari Tabel 8 terlihat nilai koefisien determinasi $\left(R^{2}\right)$ adjusted sebesar 0.9529 atau 95.29\% yang menunjukkan bahwa $95.29 \%$ variasi Price (Harga saham/Y) dapat dijelaskan dengan variasi variabel bebas $\mathrm{X}$ (Volume Offer Saham), sedangkan selebihnya yakni sebesar $4.71 \%$ dijelaskan oleh variabel lain diluar model.

\section{Uji Signifikansi Parsial (Uji Statistik t)}

Berdasarkan pengujian terhadap koefisien regresi metode regresi data panel dengan model Fixed Effect secara parsial menggunakan uji-t dapat dibuktikan bahwa Volume Offer Saham berpengaruh negatif signifikan terhadap Harga Saham (Y) dengan nilai probabilitasnya sebesar 0.0000 lebih kecil dari $\alpha=0.05$ atau $t_{\text {-hitung }}=3.9826$ lebih besar $\mathrm{t}_{\text {-tabel }}(\alpha, \mathrm{n}-\mathrm{k}: 5 \% ; 1.673-2)=1.664$.

Pembahasan. Pengujian Hipotesis. Hipotesis pada penelitian ini adalah Volume Offer Saham berpengaruh negatif terhadap Harga Saham. Berdasarkan hasil uji statistik diperoleh bahwa Volume Offer Saham berpengaruh negatif dan signifikan terhadap Harga Saham, sehingga hipotesis dapat diterima. Seperti teori yang ungkap oleh Umam dan Sutanto (2017), harga saham akan mengalami penurunan jika terjadi kelebihan penawaran diatas permintaan saham. Demikian juga yang diungkap Syamsir (2016), jika jumlah permintaan suatu saham lebih banyak daripada penawarannya maka harga saham akan cenderung mengalami kenaikan harga. Dari hasil penelitian ini terdapat kesesuaian dengan teori, jatuhnya harga saham dalam kelompok JII disebabkan karena terjadi kelebihan penawaran saham. Kelebihan penawaran saham ini mencerminkan banyaknya investor di bursa yang melepas atau menjual sahamnya dalam kondisi merebaknya Covid-19, karena sentimen negatif dari investor.

Hasil penelitian ini membuktikan bahwa volume offer saham berpengaruh negatif terhadap harga saham, artinya jika volume offer saham meningkat akan menyebabkan harga saham menurun.

Faktor penyebab banyak investor di bursa yang melepas sahamnya secara teoritis salah satu faktor eksternalnya adalah faktor panik (Beranda Sikapi Uangmu/OJK), dan secara praktis Gubernur BI, Perry Warjiyo kepada pers di Jakarta, pada Jumat (28/2/2020) yang mengungkapkan :

"pergerakan nilai tukar rupiah dan bursa yang cenderung melemah terpengaruh oleh perilaku investor global yang resah dengan penyebaran virus corona. 
Kekhawatiran pelaku pasar keuangan itu muncul setelah dampak virus asal Wuhan, Hubei, China itu, meluas tidak hanya di Asia, namun hingga Amerika Serikat, Afrika, dan Eropa." Lebih lanjut Perry mengungkapkan, "Kondisi ini menyebabkan investor global cenderung melepas investasi portofolio di Korea, Thailand, Malaysia, Singapura dan Indonesia."

Investor global cenderung melepas investasi portofolio karena resah dengan penyebaran virus corona sebagaimana yang diungkap oleh Gubernur BI, tetapi juga terdapat faktor lain seperti yang diungkap oleh Christopher (VP Equity Research PT RHB Sekuritas Indonesia) melalui wawancara dengan CNBC Indonesia, Selasa (28/4/2020) :

"arus modal keluar dari pasar saham cukup deras lantaran pasar saham di negaranegara maju seperti Amerika Serikat (AS) dan Eropa lebih banyak mendapatkan stimulus dari pemerintah". Lebih lanjut Christopher mengungkapkan :

"Di Negeri Abang Sam, pemerintah AS berani membeli obligasi dengan rating sampah alias junk, ini dilakukan untuk mencegah terjadinya krisis kredit."

"Pasar di negara AS, Eropa lebih banyak stimulus dari pemerintah, wajar investor keluar dari emerging (pasar negara berkembang) karena risiko debt lokal lebih berisiko dibanding pasar negara maju."

Berdasarkan sumber IDX Chanel.Com (diunggah April 2020), aliran keluar modal asing atau nett outflow dari pasar keuangan Inonesia di catat Bank Indonesia (BI) mencapai Rp 30,3 triliun sepanjang Februari 2020. Rinciannya terdiri dari outflow dari Surat Berharga Negara (SBN) sebesar Rp 26,2 triliun dan Rp 4,1 triliun dari pasar saham.

Dari pendapat Gubernur BI dan Christopher tersebut dapat disimpulkan bahwa jatuhnya harga saham di Bursa Efek Indonesia disebabkan karena :

- Banyak investor global (asing) yang melepas saham karena resah dengan penyebaran virus corona.

- Akibat pelepasan saham oleh investor asing, maka menyebabkan adanya arus modal keluar dari pasar saham cukup deras lantaran pasar saham di negara-negara maju seperti Amerika Serikat (AS) dan Eropa lebih banyak mendapatkan stimulus dari pemerintah.

- Investor asing melepas sahamnya karena Pasar di negara AS, Eropa lebih banyak stimulus dari pemerintah.

- Investor keluar dari emerging khawatir meningkatmya debt (hutang) emiten-emiten di negara emerging tersebut lebih tinggi risikonya dibanding pasar negara maju.

Dalam kondisi normal (diluar pandemi Covid-19), hasil penelitian ini juga mendukung penelitian yang dilakukan oleh Tenriola \& Akramunnas (2017) dan Tri Nendhenk \& Masdar (2019) menemukan volume perdagangan saham dalam kondisi permintaan yang lebih besar dari penawaran berpengaruh positif dan signifikan terhadap harga saham. Widayanti \& Mulyo (2013) menemukan volume perdagangan saham berpengaruh positif dan signifikan terhadap return saham. Bram dan Setiawan (2007) menemukan hasil bahwa volume perdagangan saham berpengaruh positif dan signifikan terhadap return saham. 


\section{SIMPULAN DAN KETERBATASAN}

Simpulan. Penelitian ini bertujuan menguji pengaruh Volume Offer Saham terhadap Harga Saham pada kondisi pandemi virus Covid-19 dengan studi empiris pada sahamsaham Jakarta Islamic Index di Bursa Efek Indonesia dengan menerapkan model regresi data panel. Metode regresi data panel merupakan kombinasi dari data time series dengan sepuluh periode pengamatan (2 Januari 2020 - 30 April 2020) dan data cross section dengan 20 saham syariah yang terpilih sebagai sampel penelitian. Hasil penelitian ini menemukan Volume Offer Saham berpengaruh negatif dan signifikan terhadap Harga Saham kelompok Jakarta Islamic Index di BEI pada kondisi pandemi virus Covid-19.

Keterbatasan dan Saran. Dalam rangka untuk pengembangan lebih lanjut dari hasil penelitian ini, maka dapat mempertimbangkan variabel lain yang diduga dapat memengaruhi Harga Saham dalam kondisi Pandemi Covid-19. Jumlah sampel untuk penelitian selanjutnya dapat menambah sampel diluar saham-saham dalam kelompok JII. Model analisis dalam penelitian ini menggunakan regresi data panel, bagi penelitian yang akan datang dapat mempertimbangkan metode regresi berganda, sebagai upaya untuk mendapatkan hasil analisis data yang lebih akurat.

\section{REFERENSI}

Ang Robert.1997. Buku Pintar Pasar Modal Indonesia. Media Staff. Jakarta

Alwi, Iskandar Z. 2008. Pasar Modal Teori dan Aplikasi, Yayasan Pancur Siwah. Jakarta

Ariyani Indriastuti dan Zumrotun Nafiah.2017. Pengaruh Volume perdagangan, Kurs dan Risiko Pasar terhadap Return Saham. Jurnal STIE SEMARANG ,VOL 9 No. 1 Edisi Februari 2017

Beranda Sikapi Uangmu (OJK)

Bram Hardianto, Roni Setiawan. 2007. Pengaruh Volume Perdagangan, EPS dan PER Terhadap Harga Saham Sektor Pertambangan pada Periode 2000-2005 di Bursa Efek Jakarta. Jurnal Manajemen, Vol. 7, No. 1

CNBC Indonesia

CNN Indonesia

Fahmi, Irham. 2014. Manajemen Keuangan Perusahaan Dan Pasar Modal. Mitra Wacana Media. Jakarta

Ghozali, Imam. 2014. Ekonometrika Teori, Konsep dan Aplikasi dengan IBM SPSS 22, Universitas Diponegoro. Semarang

IDX Chanel.Com

IndoPremier (www.indopremier.com)

Investing.com

Jogiyanto, Hartono. 2017. Teori Portofolio dan Analisis Investasi. Edisi kesepuluh, BPFE. Yogyakarta 
Kontan.co.id

Muhammad Yusra. 2019. Pengaruh Frekuensi Perdagangan, Trading Volume, Nilai Kapitalisasi Pasar, Harga Saham, dan Trading Day terhadap Return Saham pada Perusahaan Kosmetik dan Keperluan Rumah Tangga di Bursa Efek Indonesia. Jurnal Akuntansi dan Keuangan Volume 7, Nomor 1, Februari 2019

Pengumuman BEI No Peng-00555/BEI.POP/11-2019

Peraturan OJK Nomor 17/POJK.04/2015 tentang Penerbitan dan Persyaratan Efek Syariah Berupa Saham oleh Emiten Syariah atau Perusahaan Publik Syariah

Peraturan OJK Nomor 35/POJK.04/2017 tentang Kriteria dan Penerbitan Daftar Efek Syariah

Sugeng Abidin Suhadak dan Raden Rustam Hidayat. 2016. Pengaruh Faktor-Faktor Teknikal terhadap Harga Saham (Studi Pada Harga Saham IDX30 di Bursa Efek Indonesia PeriodeTahun 2012-2015). Jurnal Administrasi Bisnis (JAB). Vol. 37 No. 1 Agustus2016

Syaiful Millah (29 Maret 2020). Bisnis.com

Syamsir, Hendra. 2006. Solusi Investasi di Bursa Saham Indonesia Pendekatan Analisis Teknikal melalui Studi Kasus Riil dengan Dilengkapi Formulasi MetaStock. Elex Media Komputindo. Jakarta

Tandelilin, Eduardus. 2010. Portofolio dan Analisis Investasi Teori dan Aplikasi, Edisi Pertama. Kanisius. Yogyakarta

Tenriola Samsuar dan Akramunnas. 2017. Pengaruh Faktor Fundamental dan Teknikal terhadap Harga Saham Industri Perhotelan yang terdaftar di Bursa Efek Indonesia. MASHRAFIYAH, Jurnal Ekonomi, Keuangan dan Perbankan Syariah, Volume 1, Nomor 1 Oktober 2017: 116-131

Tri Nendhenk Rahayu dan Masdar Masud. 2019. Pengaruh Tingkat Suku Bunga, Nilai Tukar Rupiah dan Volume Perdagangan Saham Terhadap Harga Saham Perusahaan Manufaktur. PARADOKS Jurnal Ilmu Ekonomi e-ISSN .Volume 2 Nomor 2 (2019) April

Umam, Khaerul dan Sutanto, Herry. 2017. Manajemen Investasi. Pustaka Setia. Bandung

Widayanti, Puri, dan A.Mulyo Haryanto Analisis Pengaruh Faktor Fundamental dan Volume Perdagangan Harga saham Terhadap Return Saham (Studi Kasus Pada Perusahaan Real Estate and Property yang Terdaftar di BEI Periode 2007-2010). Diponegoro Journal of Management, Volume 2, Nomor 3, Tahun 2013 